\title{
Age constraints of rock glaciers in the Southern Alps/New Zealand - Exploring their palaeoclimatic potential
}

\author{
Stefan Winkler' and Christophe Lambiel ${ }^{2}$
}

\begin{abstract}
Two rock glaciers in the valley head of Irishman Stream in the central Ben Ohau Range, Southern Alps/New Zealand, have been investigated using the electronic Schmidt-hammer (SilverSchmidt). Longitudinal profiles on both features reveal a consistent trend of decreasing $R($ Rebound)-values and, hence, increasing weathering intensity and surface-exposure age on their numerous transverse surface ridges from rooting zone towards the front. Previously published numerical ages obtained by terrestrial cosmogenic nuclide dating (TCND) allowed the calculation of a local Schmidt-hammer exposure-age dating (SHD) age-calibration curve by serving as the required fixed points. Age estimates for the lowermost rock glacier surface ridges fall within the early Holocene between 12 and 10.5 ka and indicate a fast disappearance of the Late Glacial glacier formerly occupying the valley head, followed by the initiation of rock glacier formation around or shortly after the onset of the Holocene. Although it cannot be judged whether the rock glaciers investigated were active within the entire Holocene or only repeatedly during multiple episodes within, their location and intact morphology exclude any substantial glacial activity at Irishman Stream during the Holocene. This has considerable regional palaeoclimatic implications because it opens for the hypothesis that climatic conditions during early Holocene were possibly comparatively dry and favourable for rock glacier initiation, but less so for glaciers. It would also challenge the view that air temperature is the sole major climate driver of glacier variability in the Southern Alps. More work utilising the palaeoclimatic potential of rock glaciers in the Southern Alps is advised.
\end{abstract}

\section{Keywords}

electronic Schmidt-hammer (SilverSchmidt), Holocene palaeoclimate, New Zealand, rock glaciers, Schmidt-hammer exposure-age dating (SHD), Southern Alps

Received 6 October 2017; revised manuscript accepted 8 October 2017

\section{Introduction}

Rock glaciers are ice-rich debris creeping with velocities of some centimetres to some metres per year. Their genesis has been largely discussed and two main modes of rock glacier formation have been proposed (Barsch, 1988, 1996; Clark et al., 1998; Haeberli et al., 2006; Humlum, 1988; Whalley and Martin, 1992): (1) periglacial rock glaciers resulting from the creep of ice-rich sediments in permafrost conditions and (2) glacigenic rock glaciers deriving from the burial of small glaciers, mainly located in continental areas.

Their development and evolution is highly sensitive to climatic parameters (Brazier et al., 1998; Humlum, 1998; Kääb et al., 2007); rock glaciers constitute thus an important potential as archive for the regional Late Glacial and Holocene palaeoclimatology. Furthermore, rock glacier activity does exclude concurrent glacial activity. Their occurrence at specified location potentially suitable for glaciers may, therefore, bear implications and act as a proxy for limited extensions of glaciers within wider regions at certain times (Böhlert et al., 2011a, 2011b). The general palaeoclimatic potential of such locations within the transition between glacial and periglacial process systems has recently been highlighted by Matthews et al. (2017).

The dating of rock glaciers has been the subject of several studies, indicating that in many cases, relict rock glaciers mainly formed during the Late Glacial, whereas currently active rock glaciers predominantly formed during the Holocene (e.g. Barsch,
1996; Scapozza, 2015). Dating methods applied (see Haeberli et al. (2003) for a review) involve relative-age dating methods such as, for example, the Schmidt-hammer (Kellerer-Pirklbauer et al., 2008; Scapozza et al., 2014) or weathering-rind thickness (Frauenfelder et al., 2005); numerical age-dating methods (radiocarbon dating: Haeberli et al., 1999; terrestrial cosmogenic nuclide dating (TCND): Böhlert et al., 2011a; Cossart et al., 2010a; optical stimulated luminescence: Fuchs et al., 2013); or age estimations based on current velocity fields measured with aerial photogrammetry (Frauenfelder et al., 2005). These studies generally reveal considerable age variations on global and hemispheric scales. For instance, Böhlert et al. (2011a) provide evidence of two phases of rock glacier formation immediately following glacier retreat at the end of the Younger Dryas and another subsequent phase starting between 10,000 and 6000 years

'Institute of Geography and Geology, Julius-Maximilians-Universität Würzburg, Germany

${ }^{2}$ Institute of Earth Surface Dynamics, University of Lausanne, Switzerland

\section{Corresponding author:}

Stefan Winkler, Institute of Geography and Geology, Julius-MaximiliansUniversität Würzburg, Am Hubland, 97074 Würzburg, Germany. Email: stefan.winkler@uni-wuerzburg.de 
ago in the European Alps. Early-Holocene ages of 10,000-8000 years are also reported by Kellerer-Pirklbauer et al. (2008) and Kellerer-Pirklbauer (2008) from northern Europe, whereas a start of formation just prior or during the Holocene Thermal Maximum is given by Scapozza (2015) for the Swiss Alps. Younger ages were, however, obtained by Cossart et al. (2010) who propose late-Holocene ages of 2500 years in the French Alps. These patterns likely reflect different regional palaeoclimatic developments during the Holocene and underline their potential as climate proxies.

Although not uncommon within the dryer eastern parts of the Southern Alps, New Zealand, comparatively few previous studies (e.g. Brazier et al., 1998; Jeanneret, 1975; Kirkbride and Brazier, 1995) have focused on the spatial distribution of rock glaciers or their dynamics and evolution (see Sattler et al., 2016). The first complete rock glacier inventory for the Southern Alps has only been completed recently (Sattler et al., 2016) and neither a systematic monitoring programme nor detailed recent studies on their age constraints have yet been undertaken. In our study area, the Ben Ohau Range, rock glaciers have been incorporated in the subdivision of Holocene deposits by Birkeland (1982) and their stratification classification would suggest an early late-Holocene age (3000-4000 years old), previous work of McGregor (1967) even a somewhat younger age. But because these old studies mainly apply relative-age dating methods and, for example, significantly underestimate the ages of Late Glacial/early-Holocene moraines studied by Kaplan et al. (2010), these old age estimates seem unreliable (see below). Many rock glaciers in the Southern Alps are located in cirques or valley heads formerly occupied by glaciers during the Late Glacial. Obtaining information about the timing of rock glacier initiation alongside age constraints for their successive development and dynamics will, therefore, yield evidence about the retreat of glaciers and a related decrease of glacial activity at those sites to potentially help understanding the regional palaeoclimatic conditions during the Late Glacial/Holocene transition and the early Holocene.

It is a common view that glacier extension in the Southern Alps has been continuously reduced during the Holocene caused by long-term warming related to an underlying increase of solar insolation following the orbital trend (Kaplan et al., 2013; Solomina et al., 2015). There is, however, to date only fragmentary reliable morphological evidence of the proposed larger earlyHolocene glacier expansion to confirm this (Kaplan et al., 2013; Putnam et al., 2012), often explained by potentially efficient erosional censoring sensu Kirkbride and Winkler (2012) in the highly dynamic geomorphological environment. Model-based glaciological studies postulating that regional Holocene glacier variability very strongly depends on air temperatures (Anderson and Mackintosh, 2006; Mackintosh et al., 2017) support such considerations. The latter view is, however, challenged by work on glacier fluctuations during the late 20th century $\mathrm{CE}$ and its conclusion that atmospheric circulation patterns and precipitation changes are equally important drivers for the maritime New Zealand glaciers (Chinn et al., 2005; Clare et al., 2002). Furthermore, the absence of widespread early-Holocene glacier advances would correspond to the glacier chronology of mid-latitudinal mountain glaciers in South America (cf. Kaplan et al., 2016; Menounos et al., 2013; Strelin et al., 2014) and underline postulated teleconnections between both regions (Fitzharris et al., 2007). Chronological studies on rock glaciers in the Southern Alps could provide an alternative way to assess this issue. Any formation of rock glaciers at early stages during the Holocene would open for the hypothesis that Late Glacial glaciers in the Southern Alps retreated faster and were more significantly retracted immediately at the onset of the early Holocene than previously anticipated. Keeping in mind that rock glaciers required permafrost for their formation, the early Holocene must (still) have been cold enough despite comparatively moderately lowered air temperatures during the Late Glacial (Doughty et al., 2013) and the following long-term warming trend during the Holocene (Kaplan et al., 2013). Therefore, retracted early-Holocene glaciers could provide a palaeoclimatic signal for climatic conditions too dry for glaciers, thus questioning the postulated strong dependency on temperature conditions only. In many northern hemispheric regions, rock glacier initiation following the mid-Holocene Thermal Optimum and even as late as during the 'Little Ice Age' (LIA) (Janke et al., 2013) reflects hemispheric climate patterns (Wanner et al., 2011). By contrast, predominant rock glacier formation in the Southern Alps taking place during the early Holocene would nicely underline different hemispheric patterns aligned with the respective palaeoclimatic conditions.

But unlike single-age landforms related to comparatively short-lived events (e.g. moraines formed during individual glacier advances), obtaining age estimates for the initiation of rock glacier formation and its subsequent development constitute a more difficult methodological task. The characteristic rock glacier morphology and dynamics require large sample sizes with any type of surface-exposure dating because every single surface boulder inhibits the potential of ongoing disturbance after its initial accumulation. Following pilot studies of using the Schmidt-hammer for (relative) dating of moraines on glacier forelands in Aoraki/Mt Cook National Park (Winkler, 2005), Schmidt-hammer exposureage dating (SHD) has subsequently been successfully applied on moraines as well as on (glacio)fluvial terraces in the Southern Alps (Stahl et al., 2013; Winkler, 2009, 2014). In particular, the widespread and comparatively homogeneous 'greywacke' of the Torlesse composite terrane dominating east of the Main Divide (Cox and Barrell, 2007) has proven to be suitable for Schmidthammer studies, even indicating potential for the development a regional age-calibration curve like Matthews and Owen (2010) did in Southern Norway (Winkler and Corbett, 2014). But whereas the Schmidt-hammer has already been applied on rock glaciers in the European Alps, Iceland and Norway (e.g. Böhlert et al., 2011b; Frauenfelder et al., 2005; Kellerer-Pirklbauer et al., 2008; Matthews et al., 2013; Rode and Kellerer-Pirklbauer, 2011; Scapozza et al., 2014), neither rock glaciers nor any other periglacial landforms have previously been sampled in the Southern Alps of New Zealand.

The primary aim of our study is to test whether SHD can successfully be applied on rock glaciers in the Southern Alps and to compare the results obtained with those of similar studies on rock glaciers elsewhere. We will, furthermore, calculate a local SHD age-calibration curve by using fixed points in the form of TCND ages previously published by Kaplan et al. (2010) to gain age constraints for the rock glaciers investigated and enable interpretation of their initiation and dynamics. Finally, by comparing this information with established glacier chronologies, the potential of further studies on rock glaciers as palaeoclimatic archives will be discussed briefly.

\section{Study area}

The high-altitude valley head of Irishman Stream in the Ben Ohau Range between Lakes Ohau and Pukaki is located roughly $30 \mathrm{~km}$ southeast of the Main Divide of the Southern Alps. It contains a number of separate rock glaciers - two selected for this study (Figures 1-3). Rock glacier 1 is a $400 \mathrm{~m}$ long landform composed of a succession of ridges and furrows. Altitudes range from $1870 \mathrm{~m}$ a.s.l. at the front to $1990 \mathrm{~m}$ a.s.l. at the rooting zone (or head), which places this rock glacier below the suggested lower limit of modern permafrost at c. $2000 \mathrm{~m}$ a.s.l. (Brazier et al., 1998; Kirkbride and Brazier, 1995) and the modelled permafrost distribution by Sattler et al. (2016). Whereas rock glacier 1 is the lowermost rock glacier in the entire valley 


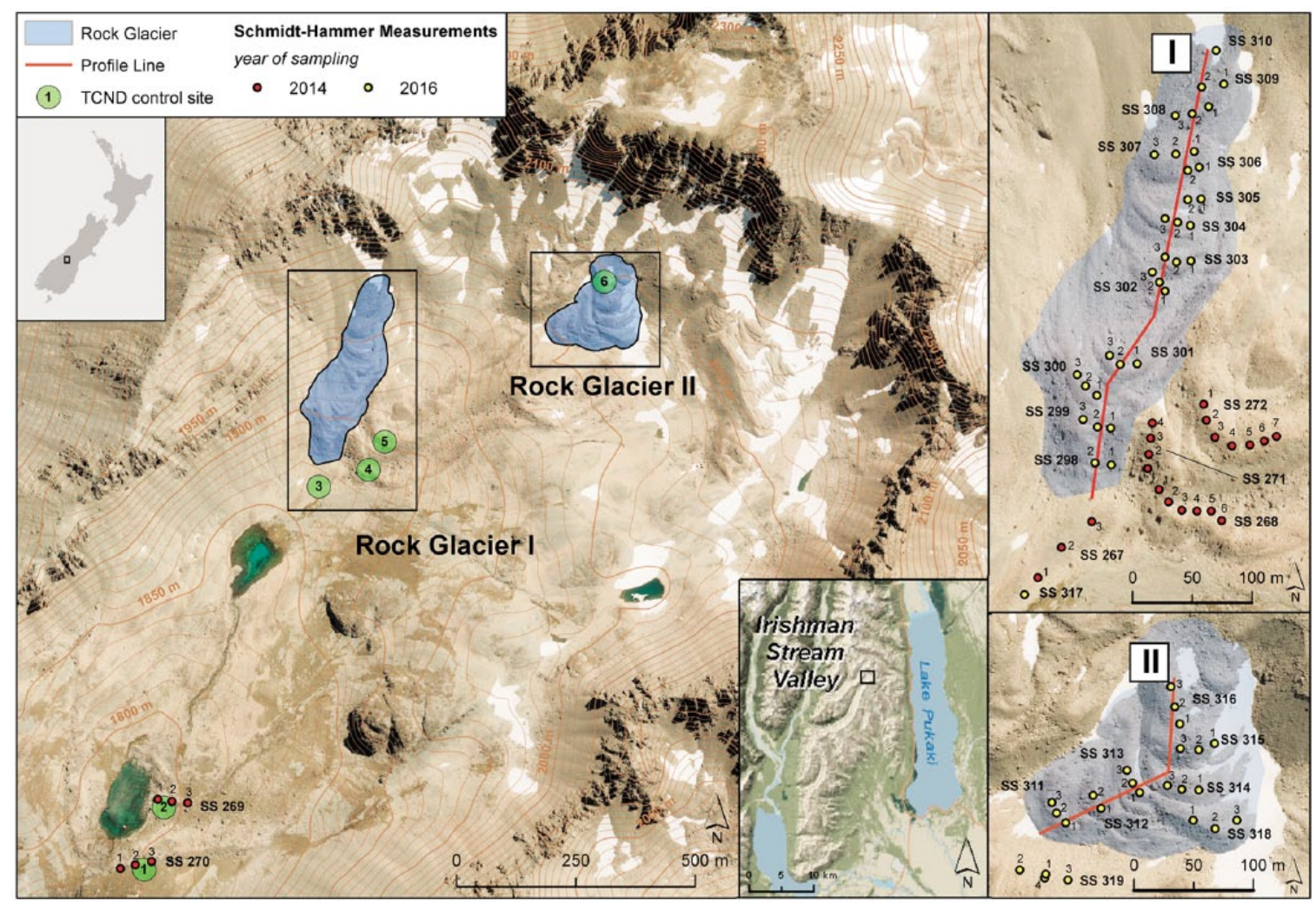

Figure I. Aerial orthophoto with contours of the Irishman Stream valley head and its location within New Zealand and the Ben Ohau Range, respectively (inserts). Main contours show 50-m intervals, auxiliary ones 10-m intervals. The longitudinal profiles for Schmidt-hammer sampling on the two rock glaciers studied are shown alongside individual sample sites of 2014 and 2016. The TCND control sites refer to the ages published by Kaplan et al. (2010), complemented by 'young' control site No.6 (see text for further details; modified from Land Information New Zealand's online database http://www.linz.govt.nz).

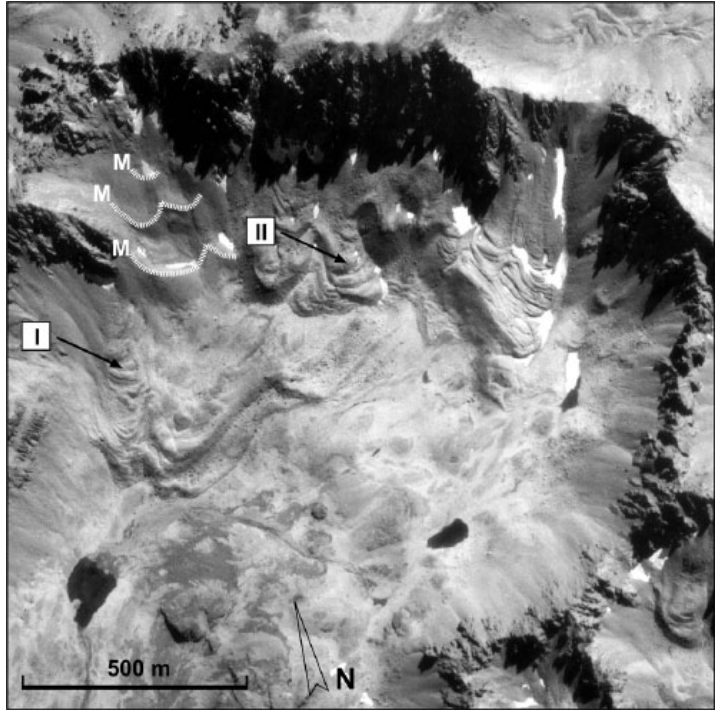

Figure 2. Aerial photo taken 3 March 1960 (non-rectified) depicting the detailed morphology of the rock glaciers of the Irishman Stream valley head. The rock glaciers investigated (I and II) are indicated (cf. Figure I), also three presumed lateHolocene/'Little Ice Age' moraines not investigated here in detail (see text; cf. Birkeland, 1982; Kaplan et al., 2010).

head, rock glacier 2 just reaches down to $c .2000 \mathrm{~m}$ a.s.l. It comprises two separate segments indicated by a prominent bend in its flow line between ridges 3 and 4 at about 2025/2030 m a.s.l. (Figure 1). The upper part trending relatively straight $\mathrm{N}-\mathrm{S}$ appears to have marginally overridden the lower part, indicating a possible two-phase development.
The bedrock of the central Ben Ohau Range belongs to the Rakaia terrane of the Torlesse composite terrane, mostly undifferentiated dated as Permian to Triassic age (see Cox and Barrell (2007) for details). The original quartzofeldsphatic sandstones interbedded with silt and mudstones become more strongly metamorphosed and deformed towards the Alpine Fault northwest of our study area, but east of the Main Divide, 'greywacke' dominates. The 'massive' appearance of this rock type has previously proven to be suitable for Schmidt-hammer measurements (Stahl et al., 2013; Winkler, 2005). It weathers comparatively slowly while changing its fresh greyish surfaces into pinkish colours. This coincides with selective surface weathering and the common thin quartz veins, avoided with Schmidt-hammer sampling, stick out by up to $10 \mathrm{~mm}$ on Late Glacial boulders. But in general, the surface morphology of boulders is minimal and of no concern for the reliability of Schmidt-hammer measurements.

No detailed meteorological data are available for the study area. Mean annual air temperatures (MAAT) for active rock glaciers in the Southern Alps have been modelled to be positive and among the highest reported on a global scale (see Sattler, 2016; Sattler et al., 2016, for details). MAAT for Irishman Stream Valley head should be around $0^{\circ} \mathrm{C}$ or slightly above at $2000 \mathrm{~m}$ a.s. 1 and it has a southerly aspect. The high annual precipitation likely exceeds $10,000 \mathrm{~mm}$ on western slopes and, thanks to an 'overspill' effect, is also typical for the Main Divide of the Southern Alps itself and areas immediately to its east (Chater and Sturman, 1998; Griffiths and McSaveney, 1983; Henderson and Thompson, 1999). But it does not reach the central Ben Ohau Range. Irishman Stream is located east of the $2000 \mathrm{~mm}$ isohyet (Sattler, 2016; Tait et al., 2006). It seems too dry to support considerable Holocene glaciation, thus allowing the formation of rock glaciers practically absent in the more westward parts of the Southern Alps. 


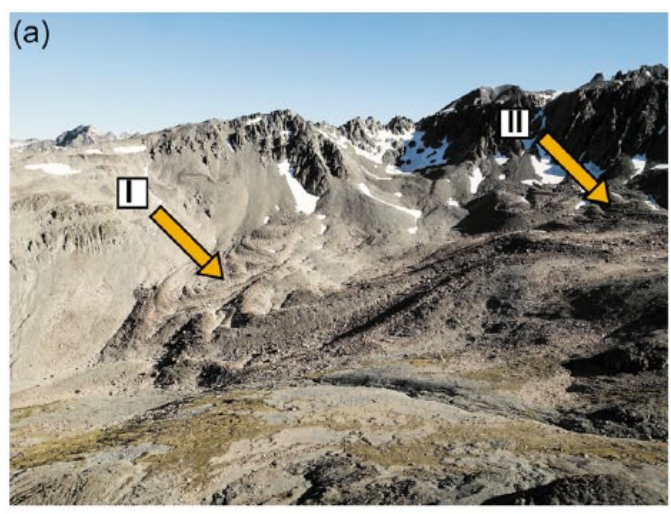

(c)
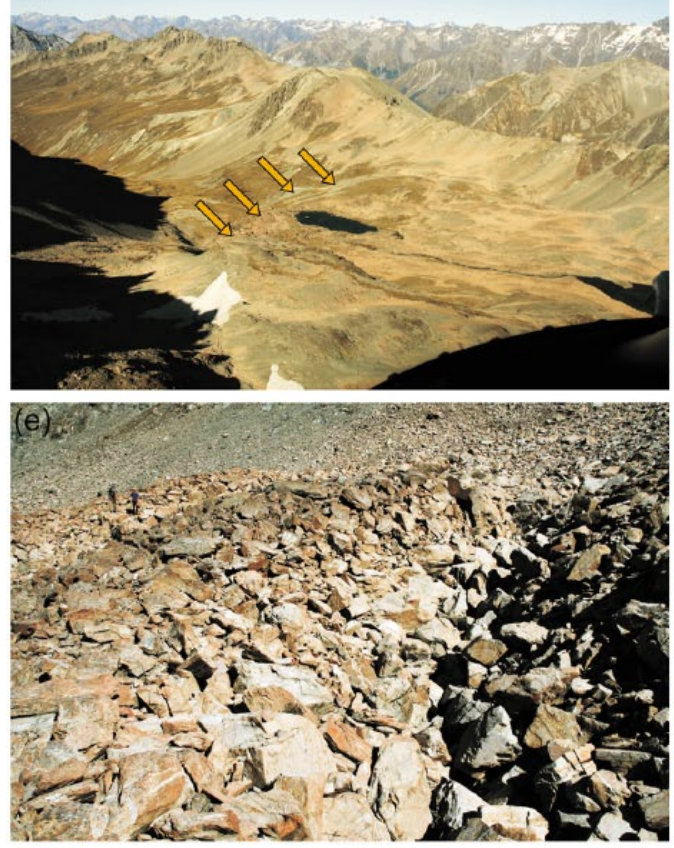

(b)

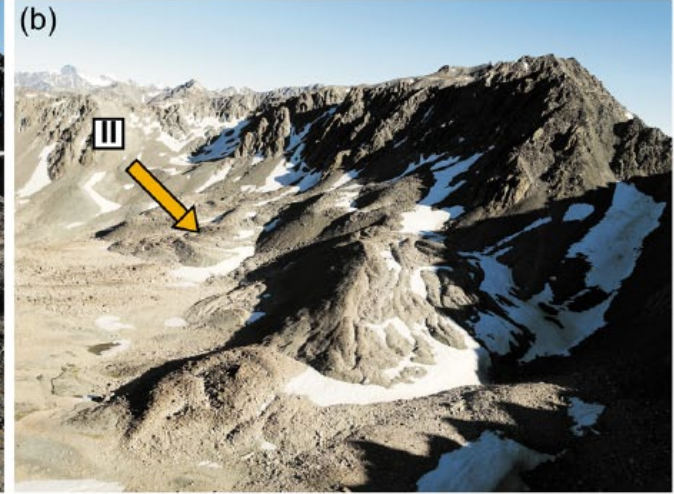

(d)
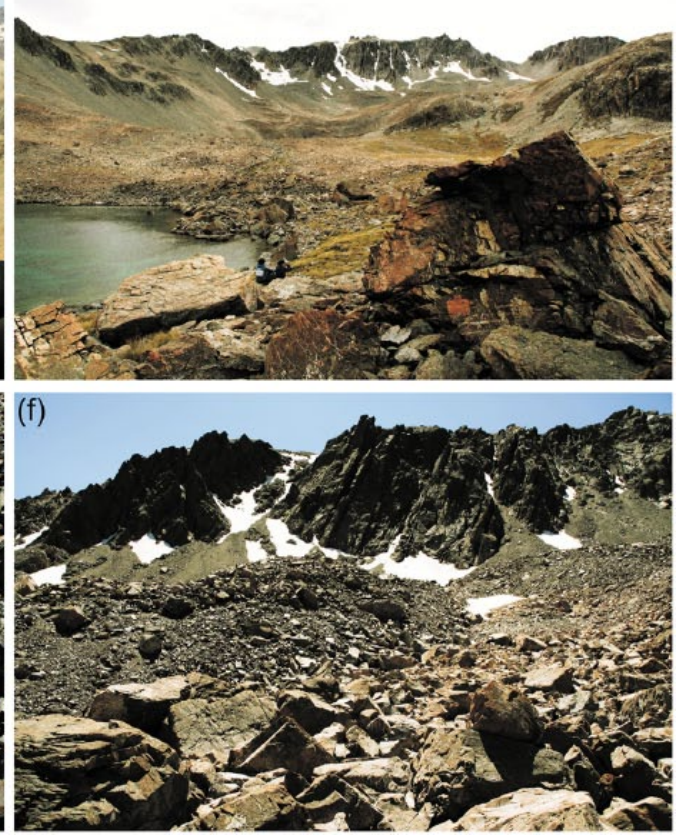

Figure 3. Irishman Stream valley head photos taken on 10 January 2016 and 15 February 2014 (Figure 3d): (a) The western valley head with the rock glaciers I and 2 investigated in this study (cf. Figures I and 2); (b) the eastern valley head with additional rock glaciers showing morphological signs of activity. (c) Displays the Late Glacial moraines of the former Late Glacial Irishman Stream Glacier as seen towards the south (outermost Late Glacial moraine indicated by arrows); (d) depicts a view from TCND fixed point 2 in northern direction towards rock glaciers and the valley headwall. (e) The typical ridge-and-furrow surface morphology of rock glacier; (f) was taken near the rooting zone of rock glacier 2 .

\section{Methods}

\section{Schmidt-hammer measurements}

Schmidt-hammer measurements were carried out in February 2014 and January 2016. Electronic Schmidt-hammers (SilverSchmidt) of the N-type configuration with calibrated impact energy of $2.207 \mathrm{Nm}$ for the plunger (Proceq SA, 2012) were chosen to ensure high efficiency with acquiring substantial raw data in limited time. Although not attempted in our study, Winkler and Matthews (2014) have previously shown that Q-(velocity) values obtained by electronic Schmidt-hammers are interconvertible with $R$-(rebound) values of mechanical instruments, thus allowing comparison with existing data series. For simplification, all SilverSchmidt Q-values indicating compressive strength of the boulder surfaces sampled when measured using an inbuilt sensor to record the rebound velocity of the plunger independent of its impact direction are called 'R-values' hereafter. This anticipates the manufacturer's decision to re-name impact data 'R-values' with the improved version of the electronic Schmidt-hammer (RockSchmidt; cf. Proceq SA, 2014; Winkler et al., 2016). All instruments used during fieldwork were checked for their calibration to the manufacturer's specifications. Detailed data from related preand post-fieldwork tests on the specific manufacturer's test anvil additionally allowed correcting the raw data for minor differences $(\sim R=1)$ that otherwise simply would have fallen within the acceptable range of tolerance for calibration.

Abundance of boulders suitable for sampling and character of the landforms investigated (rock glaciers and moraines) called for an established sampling design of single impacts on large numbers of boulders. With one impact each on 50 randomly selected boulders and multiple samples (preferably 3 or more) on every individual site, potential postdepositional disturbance in highalpine environments was also addressed, and preferable to designs using multiple impacts on fewer boulders. Individual samples were finally combined for every site after they had shown consistency without outliers. They are reported in the accepted standard format as mean $R$-values with $95 \%$ confidence $(\alpha=0.05)$ following Shakesby et al. (2006) and others using the equation:

$$
\bar{X} \pm t s / \sqrt{(n-1)}
$$

where $\bar{X}=$ arithmetic mean, $s=$ sample standard deviation, $t=$ Student's $t$ statistic and $n=$ number of impacts (sample size). Because the rock glacier sites were initially expected to resemble a diachronous rather than a synchronous surface (i.e. with a considerable spread 
Table I. Fixed points for the SHD age-calibration curve at Irishman Stream.

\begin{tabular}{llllll}
\hline Site & $R$-value & $n$ (boulders) & TCND age & $n$ (samples) & Sample IDs $^{\mathrm{b}}$ \\
\hline $\mathrm{I}$ & $54.18 \pm 1.84$ & 100 & $13100 \pm 339$ & 6 & $06-31-33,06-35-37$ \\
2 & $55.04 \pm 1.46$ & 150 & $12800 \pm 300$ & 2 & $06-41 / 42$ \\
3 & $55.49 \pm 1.28$ & 200 & $12100 \pm 300$ & 1 & $06-47$ \\
4 & $57.32 \pm 1.08$ & 300 & $11900 \pm 300$ & 1 & $06-28$ \\
5 & $54.58 \pm 1.06$ & 350 & $11650 \pm 490$ & 2 & $06-26 / 27$ \\
6 & $69.47 \pm 1.26$ & 50 & $100 \pm 100^{d}$ & - & - \\
\hline
\end{tabular}

SHD: Schmidt-hammer exposure-age dating;TCND: terrestrial cosmogenic nuclide dating.

$R$-values and numerical ages of the selected fixed points for the SHD age-calibration curve of the Irishman Stream valley head (for position and altitude cf. Figure I; see also text and Kaplan et al. (2010) for the original TCND dataset and their sample IDs; Kaplan et al. used the ${ }^{10}$ Be-production model of Putnam et al. (20I0), the only regional calibration scheme available for the Southern Alps to date).

a Mean of $R$-values (SilverSchmidt) with 95\% confidences ( $\alpha=0.05)$.

bTCND ages calculated on the basis of results published by Kaplan et al. (2010). With more than one sample, the arithmetic mean has been calculated (see text).

'Original TCND sample IDs of Kaplan et al. (20I0).

'‘Young' fixed point (see text).

of exposure ages as revealed by their $R$-values), detailed histograms were produced for all sites for further interpretation. Except Kolmogorov-Smirnov tests for normality, no further statistical analysis was performed at this stage.

In 2014, sampling was primarily carried out on Late Glacial and early-Holocene moraines ridges investigated by Kaplan et al. (2010) that eventually were used as fixed points for the calculation of SHD age-calibration curves (see below). Apart from one site that was re-sampled to ensure reproducibility, sampling in 2016 focused on the selected rock glaciers in the form of two longitudinal profiles from front to their rooting zone. Every individual transverse surface ridge along these profiles mapped with a differential GPS was sampled and treated as individual site. To avoid potential influence of micro-climatic and micro-weathering differences, furrows on the rock glacier surface between those ridges were avoided (except for one test site).

\section{Calculation of Schmidt-hammer exposure-age calibration curves}

Reliable and well-documented TCND ages from Irishman Stream valley head reported by Kaplan et al. (2010) provided sufficient fixed points in the form of numerical age information required for the construction of a local age-calibration curve and subsequent application of SHD as described in detail by Matthews and Owen (2010) or Shakesby et al. (2011). Because Kaplan et al. (2010) applied the ${ }^{10} \mathrm{Be}$-production rates of Putnam et al. (2010), the only available regional calibration scheme available to date, no recalculation of their original data seemed necessary (see discussion). Late Glacial and early-Holocene moraine ridges investigated in their study have, thanks to the restricted catchment of Irishman Stream, the same source of debris with a visible dominance of dumped former supraglacial debris on their surface. Schmidthammer data were obtained on these moraines easily identifiable on the ground, supplemented by a 'young' fixed point in the form of 'fresh' appearing rock fall boulders at the uppermost rooting zone of rock glacier 2. This site was given a fixed age of $100 \pm$ 100 years as best estimate. For our fixed points, we did not use the moraine ages calculated by Kaplan et al. (2010) as arithmetic means of all related TCND ages but only those individual samples located on the actual part of the moraine ridges we sampled with the SilverSchmidt (see Figure 1). An arithmetic mean for fixed point ages was only calculated if more than one individual sample was available for the part of the moraine we sampled (Table 1). The underlying rational was to avoid any potential influence of minor lithological and micro-climatic differences, or complications caused during the uninvestigated history of moraine formation. Importance of the latter was recently highlighted at nearby
Mueller Glacier by Rezninchenko et al. (2016) who presented evidence that the use of an arithmetic mean of related TCND ages may not necessarily be an appropriate way to calculate a reliable date for moraine formation in the specific geomorphological environment of the Southern Alps.

The procedure of calculating SHD calibration curves followed recent practice established and explained in detail by Matthews and Winkler (2011), Matthews et al. (2014) or Winkler et al. (2016). In their fundamental work on an ideal study site, Shakesby et al. (2011) confirmed that the $R$-value-age relationship is best described by a linear function. Local SHD studies (Winkler, 2014; Winkler and Corbett, 2014) came to the same conclusion and correspond to linear weathering intensity-age trends applied with the weathering-rind-thickness dating method in the region (Birkeland, 1982; Chinn, 1981, and others). Even with the limited spread of available fixed points preventing better local re-assessment, initial testing also demonstrated better fit of linear versus exponential functions and provided, together with those abovementioned results, sufficient confidence about the applied shape of the SHD calibration curves that follow the standard equation for linear regression:

$$
y=a+b x
$$

where $y=$ surface age in years, $x=$ mean $R$-value, $a=$ intercept age and $b=$ slope of the calibration curve.

Using all available fixed points, the local calibration curve is defined by the equation:

$$
y=59963.1037-862.0690 x
$$

and subsequently applied for the calculation of SHD age estimates presented here. Three additional calibration curves were calculated by excluding one or two of those fixed points representing the 'inner moraines belt' of Kaplan et al. (2010). These alternative calibration curves resulted in only insignificant improvements of $R^{2}$ (Table 2) and could easily be artefacts of fewer points generally giving better fit with linear equations. Their similarity would anyway have resulted in similar age estimates within the related error ranges. Even if the possibility of postdepositional disturbance because of higher altitude of the 'inner moraines belt' located within altitudinal range of the lowermost rock glacier fronts justified initial testing, their application was not followed up. Because the TCND ages serving as fixed points were not collected as part of this study, we honestly felt unable to judge the representativeness of individual samples provided by Kaplan et al. (2010) and, therefore, decided not to exclude any. 
Table 2. Age-calibration curves calculated for Irishman Stream.

\begin{tabular}{lll}
\hline Sites included $^{\mathrm{a}}$ & Equation $^{\mathrm{b}}$ & \\
\hline All $(\mathrm{I}-\mathbf{6})$ & $\boldsymbol{y}=\mathbf{5 9 9 6 3 . 1 0 3 7 - 8 6 2 . 0 6 9 0 x}$ & $\boldsymbol{R}^{2}=\mathbf{0 . 9 3 3 4 2}$ \\
$\mathrm{I}-3,5,6$ & $y=58893.3816-847.4576 x$ & $R^{2}=0.95326$ \\
$1-4,6$ & $y=61103.3244-877.1930 \mathrm{x}$ & $R^{2}=0.94963$ \\
$I-3,6$ & $y=59989.1060-862.0699 x$ & $R^{2}=0.96459$ \\
\hline
\end{tabular}

Schmidt-hammer exposure-age dating (SHD) age-calibration curves calculated for the Irishman Stream valley head using different sets of fixed points (cf.Table I). The calibration curve finally applied on the surface ridges of rock glaciers I and 2 is printed in bold (see text; cf. Figure 6). aSee Table I and Figure I.

bResults using linear equations only included selected sites (see text).

The confidence intervals of the final SHD age estimates reflect the total error $\left(C_{t}\right)$ and combine the sampling error of the rock glacier site $\left(C_{s}\right)$ with the error of the calibration curve $\left(C_{c}\right)$ following Matthews and Winkler (2011):

$$
C_{t}=\sqrt{\left(C_{s}^{2}+C_{c}^{2}\right)}
$$

$C_{s}$ is derived from the slope of the calibration curve (b), Student's $t$ statistic and the standard error of the mean $R$-value of the rock glacier site, where $s$ is the standard deviation and $n$ is the sample size (Matthews and Owen, 2010):

$$
C_{s}= \pm b[t s / \sqrt{(n-1)}]
$$

$C_{c}$ is derived from the confidence intervals associated with the oldest fixed point $\left(C_{o}\right)$ and the young fixed point $\left(C_{y}\right)$, where $R_{o}$, $R_{y}$ and $R_{s}$ are the mean $R$-values of these two fixed points and the sampled site, respectively (Winkler et al., 2016):

$$
C_{c}=C_{o}-\left[\left(C_{o}-C_{y}\right)\left(R_{s}-R_{o}\right) /\left(R_{y}-R_{o}\right)\right]
$$

\section{Results}

Application of the electronic Schmidt-hammer, the first such attempt in the context of SHD in New Zealand, yielded a total of c. 4500 sampled boulders during the brief site visits and proved to be very efficient. The results obtained on the transverse surface ridges along the longitudinal profiles of both rock glaciers are very consistent with only one out of the 47 samples rejected as outlier (an unusual concentration of highly weathered boulders for that particular sample was already noted during fieldwork). Mean $R$-values for individual ridges were, consequently, calculated by integrating all samples obtained from each individual ridge resulting in sample sizes of 150 or (in few cases) 100 boulders (Table 3 ). Histograms are provided for these sites (Figures 4 and 5) that all passed the KolmogorovSmirnov test for normality. All surface ridges (i.e. 11 on rock glacier 1 and six on rock glacier 2) reveal a constant trend with lowest $R$-value means for the lowermost surface ridges (Figures 4 and 5). Whereas the difference between lowermost and uppermost ridges on both rock glaciers is considerable (approximately $R=10$ ), neighbouring surface ridges do in general not show any statistically significant differences in their means within the overlying trend of increasing $R$-values towards the rooting zone. Only between ridges 8 and 9 on rock glacier 1 (samples SS 305/307) and between the three upper ridges on rock glacier 2 larger gaps show that, owing to long-term development of these landforms and the chosen sample sizes, should

\begin{tabular}{|c|c|c|c|c|}
\hline ID & Site ${ }^{a}$ & $R$-value ${ }^{b}$ & $\sigma^{c}$ & $n$ (boulders) \\
\hline \multicolumn{5}{|c|}{ Rock glacier I } \\
\hline SS 298 & Ridge I & $55.58 \pm 1.90$ & 9.54 & 100 \\
\hline SS 299 & Ridge 2 & $57.40 \pm 1.35$ & 8.41 & 150 \\
\hline SS 300 & Ridge 3 & $57.26 \pm 1.90$ & 9.72 & 100 \\
\hline SS 301 & Ridge 4 & $57.84 \pm 1.4 \mid$ & 8.83 & 150 \\
\hline SS 302 & Ridge 5 & $58.96 \pm 1.47$ & 9.17 & 150 \\
\hline SS 303 & Ridge 6 & $60.49 \pm 1.23$ & 7.70 & 150 \\
\hline SS 304 & Ridge 7 & $61.65 \pm 1.08$ & 6.77 & 150 \\
\hline SS 305 & Ridge 8 & $61.16 \pm 1.50$ & 7.66 & 100 \\
\hline SS 307 & Ridge 9 & $64.91 \pm 1.19$ & 7.42 & 150 \\
\hline SS 308 & Ridge 10 & $65.10 \pm 1.15$ & 7.16 & 150 \\
\hline SS 309 & Ridge II & $65.34 \pm 1.61$ & 8.19 & 100 \\
\hline SS 310 & Rooting zone & $67.50 \pm 1.29$ & 4.67 & 50 \\
\hline SS 306 & Furrow 8/9 & $58.14 \pm 1.77$ & 9.05 & 100 \\
\hline \multicolumn{5}{|c|}{ Rock glacier II } \\
\hline SS 311 & Ridge I & $57.51 \pm 1.45$ & 9.67 & 150 \\
\hline SS 312 & Ridge 2 & $57.79 \pm 1.24$ & 6.35 & 100 \\
\hline SS 313 & Ridge 3 & $58.30 \pm 1.39$ & 8.72 & 150 \\
\hline SS 314 & Ridge 4 & $59.73 \pm 1.36$ & 8.53 & 150 \\
\hline SS 315 & Ridge 5 & $62.48 \pm 1.17$ & 7.33 & 150 \\
\hline SS 316 & Ridge 6 & $67.42 \pm 1.06$ & 6.63 & 150 \\
\hline SS 318 & $\begin{array}{l}\text { Ridge } 4 \text { (east, } \\
\text { disturbed) }\end{array}$ & $63.55 \pm 1.29$ & 8.71 & 150 \\
\hline SS 319 & $\begin{array}{l}\text { Outside rock } \\
\text { glacier }\end{array}$ & $58.85 \pm 1.21$ & 8.03 & 200 \\
\hline
\end{tabular}
not be over-interpreted.
Table 3. Schmidt-hammer data from rock glaciers I and II.

Schmidt-hammer data (mean, $95 \%$ confidence at $\alpha=0.05$, standard deviation) of all sites sampled on rock glaciers I and II (see Figures I, 4 and 5 and text for further explanation).

aSee text and Figures 4 and 5 for location of sites.

bMean of $R$-values (SilverSchmidt) with $95 \%$ confidence intervals $(\alpha=0.05)$.

'Standard deviation.

A few samples in 2016 were taken outside the surface ridges along the longitudinal profiles to gain comparative figures. A patch of highly weathered boulders in a furrow positioned between ridges 8 and 9 on rock glacier 1 (sample SS 306, Table 3) has a lower $R$-value mean than those surrounding ridges. This is possibly the result of differences in weathering intensity because of longer/deeper snow-cover and micro-climatic differences between ridges and furrows (see Ballantyne et al., 1989, 1990). It confirms the importance of our consistent sampling design to investigate surface ridges only and, furthermore, improves the reliability of the SHD calibration curve because the sampled fixed points/ TCND-locations also constitute ridges (moraines) with a similar micro-climatic environment. A sample close to a snow patch at the rooting zone of rock glacier 1 (SS 310; Table 3) perfectly fits the trend of increasing $R$-values with a mean almost identical to the uppermost ridge of rock glacier 2. On rock glacier 2, the easternmost segment of surface ridge 4 (SS 318) has a considerable higher $R$-value mean than its western counterpart (Figure 1 and Table 3 ). This can be explained by the disturbed appearance of the site (many boulders obviously rotated recently) in close proximity to the active front of the upper segment of rock glacier 2 (see 'Discussion'). Disturbance of boulders by periglacial processes, such as frost heave, is suggested to explain the slightly higher $R$-value means of samples in the foreland of rock glacier 2 (SS 319; Table 3). Summarising, the most important outcome of Schmidthammer sampling along the longitudinal profiles is a remarkable, consistent trend of increasing $R$-values means from the lowermost to the uppermost surface ridges on both rock glaciers.

The samples obtained on Late Glacial and early-Holocene moraine ridges subsequently serving as fixed points for SHD 

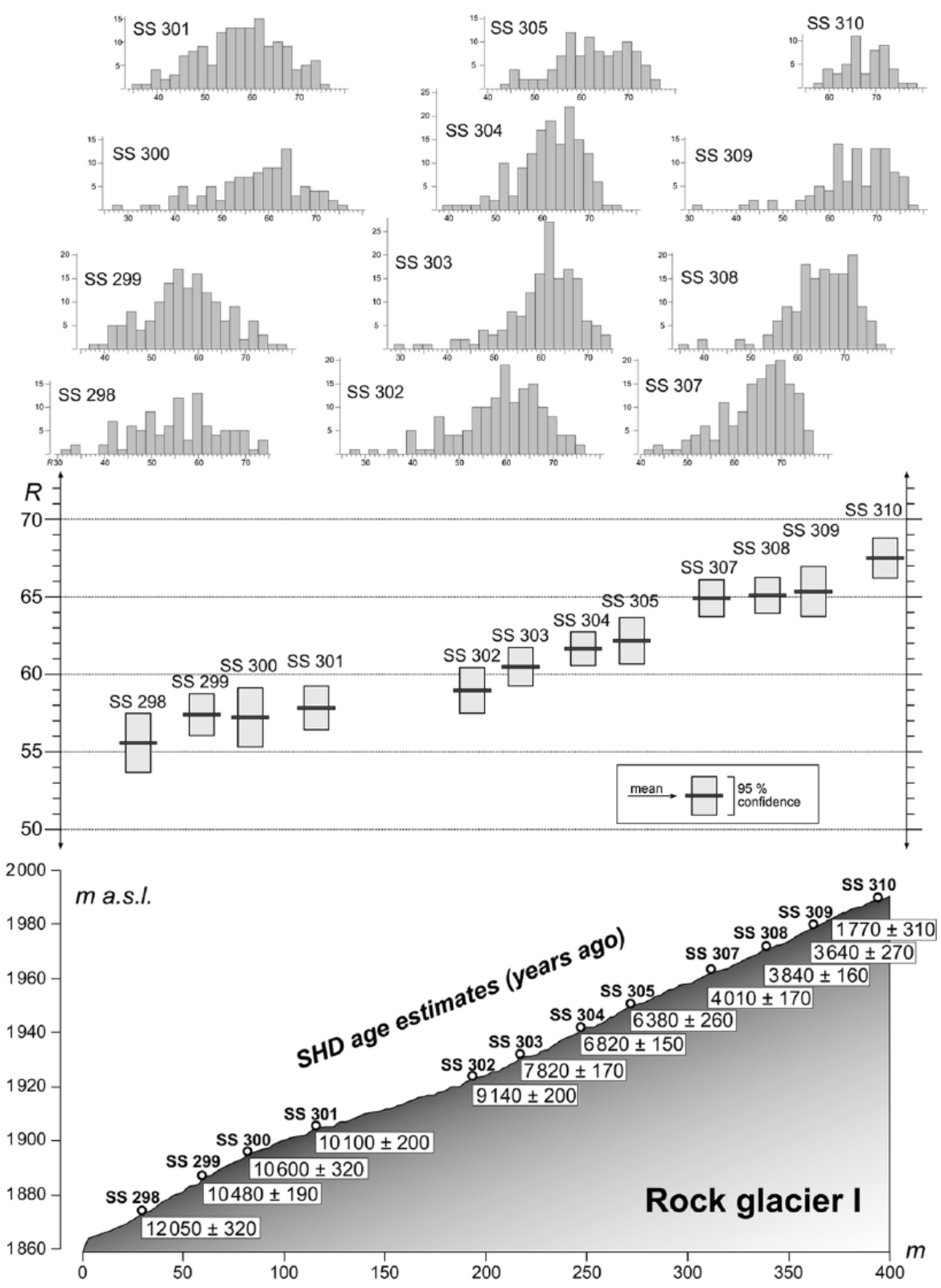

Figure 4. Schmidt-hammer $R$-values (upper panel: detailed histograms; middle panel: means and $95 \%$ confidence intervals - details see Table 3) for the longitudinal profile on rock glacier I (see Figure I). The SHD age estimates (rounded to the nearest I0 years) are derived from applying the SHD calibration curve based on all TCND control points including the young surface (cf. Figure 6 and Table 2; see text for further explanation).

age-calibration curves are comparatively consistent. Only one sample (out of 27) needed to be rejected as potential outlier. After correcting the raw data for the slight difference of instruments calibration (all 2014 data were reduced by $R=1$; see above), all samples on individual sites were integrated accordingly resulting in sample sizes between 100 and 350 boulders each (Table 1). After calculating $R$-value means for all five sites selected as 'old' fixed points, they were accompanied by sample SS 316.3 selected as 'young' fixed point on the basis of its location at the uppermost rooting zone of rock glacier 2 . It virtually comprises 'fresh' rock fall boulders only.

When applied to the lowermost surface ridge of rock glaciers 1 , the calibration curve (Figure 6) yields an age $(12,049 \pm 323$ years ago prior to rounding) that is close to the TCND ages for the earlyHolocene moraines of the 'inner moraine belt' (Kaplan et al., 2010) and only $c .1000$ years younger than the Late Glacial moraines. With an age of c. 10,500 years ago, the lowermost ridge of rock glacier 2 seems younger (Figure 5), most likely a result of the higher altitude of its rooting zone and thus glacier-free conditions commencing somewhat later. Age estimates for individual ridges along the rock glacier length profiles spread through the whole Holocene, not restricted to its early part. This opens for two alternative interpretations: (1) the rock glaciers remained active during the entire Holocene or (2) both rock glaciers experienced periods of activity interrupted by several phases of inactivity, the latter not too extensive to allow substantial modification of their morphology (see 'Discussion'). An average rate of movement in the range $c .3$ $\mathrm{cm} / \mathrm{yr}$ (calculation based on distance from rooting zone to present front and the suggested date of formation) seems more at the lower end of values reported from rock glaciers elsewhere (KellererPirklbauer, 2008; Scapozza et al., 2014) and would rather tend to support the latter alternative.

The age estimates for the rock glacier are, however, contradictory to previous work and clearly exclude substantial glacier activity during the later early, mid-, and late Holocene (Birkeland, 1982; see 'Discussion'). Any glacier advance on the rock glaciers would have modified or destroyed their typical morphology. 

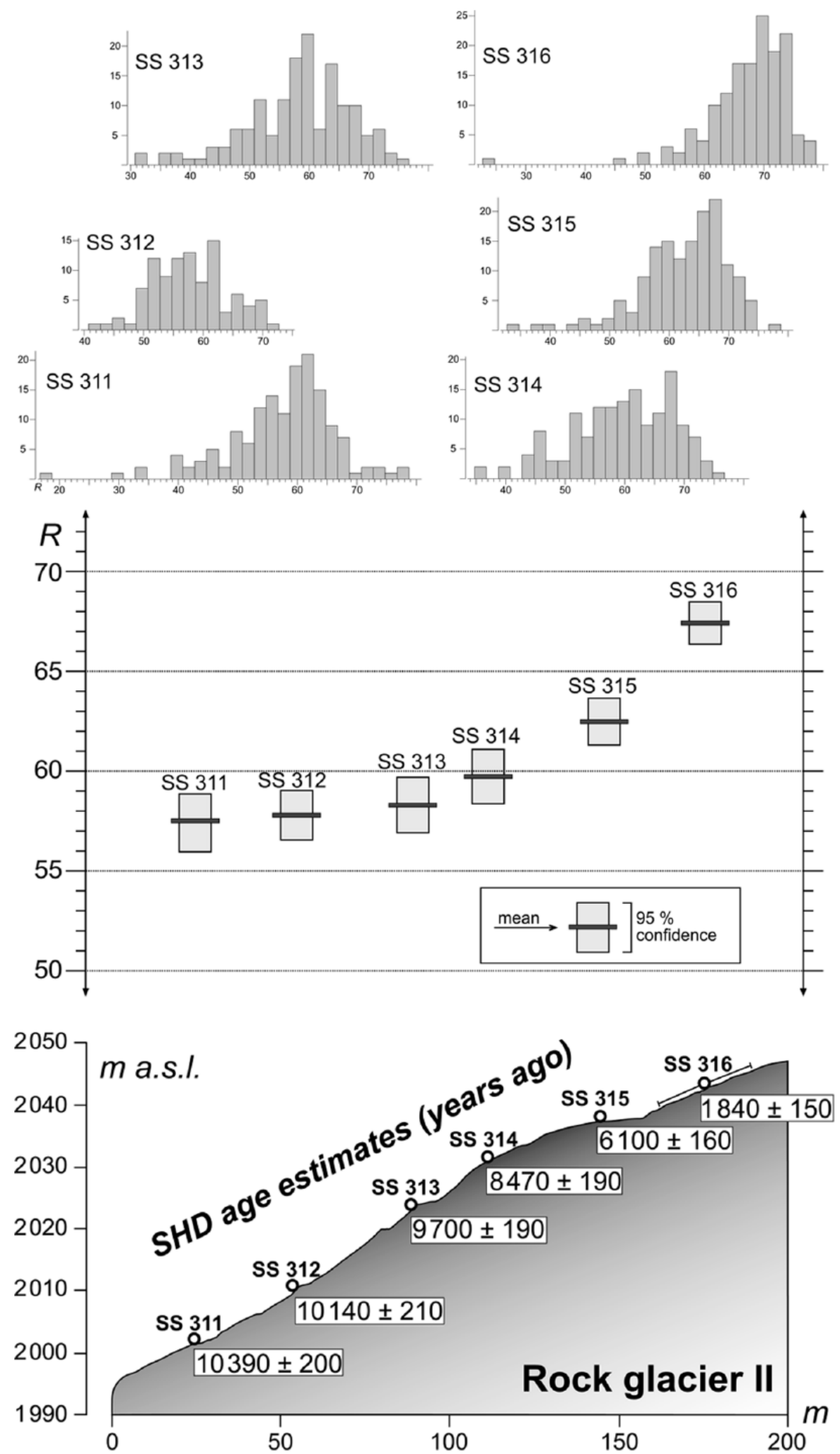

Figure 5. Schmidt-hammer R-values and SHD age estimates for rock glacier 2 (cf. Figure 4; see text).

\section{Discussion}

The consistent decrease of $R$-values (and consequently increase of surface weathering grade and exposure age) along the longitudinal profiles towards the rock glacier front corresponds well with existing studies, for example, those of Frauenfelder et al. (2005), Kellerer-Pirklbauer (2008), Rode and Kellerer-Pirklbauer (2011) or Scapozza et al. (2014). It shows that the boulders are transported more or less passively at the surface of the rock glaciers without noticeable toppling. It also requires that the surface ridges, once formed, must have been stable during the development of the rock glacier and subsequent formation of younger ridges close to its rooting zone. Otherwise, such a clear trend in the spatial evolution of the $R$-value means cannot be explained. Indeed, any toppling of a boulder would reset its 'weathering clock' to zero, and frequent toppling of individual boulders would influence the overall mean $R$-value of the ridge. Such a process is reported by Frauenfelder et al. (2005), who measured an increase of $R$-value means at the active front of some of their studied rock glaciers because of toppling and relocation of boulders. The same was observed with sample SS 318 at the eastern front of rock glacier 2, 


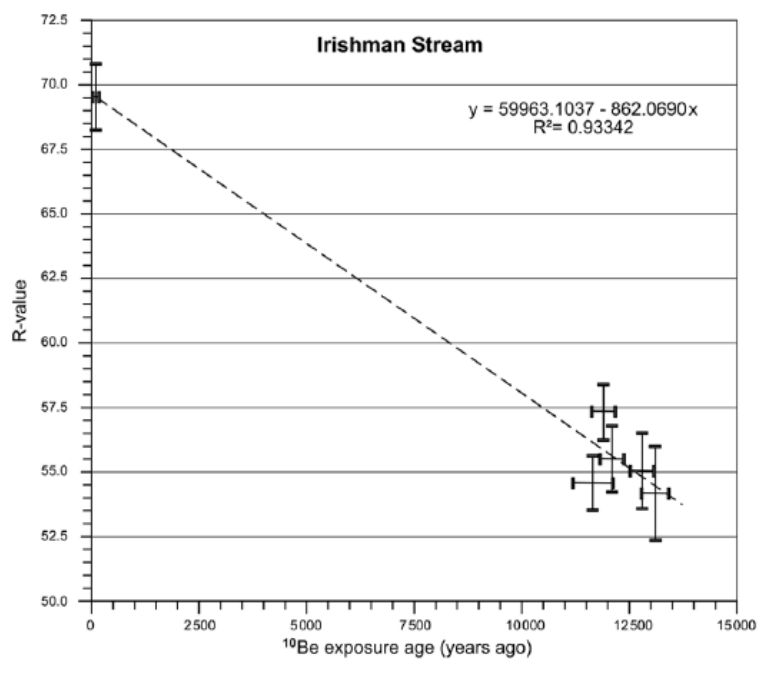

Figure 6. SHD calibration curve based on Schmidt-hammer sampling at all TCND control sites (see Tables I and 2). Errors for both TCND ages and $R$-values are indicated.

where relatively high $R$-values were measured. It confirms Sattler et al.'s (2016) and our observations that this rock glacier is still active. We disagree, however, with their statement qualifying the eastern part of this rock glacier as 'relict' because we found no geomorphological evidence for this, like depressions or front stabilisation. Finally, the large $R$-value differences measured between the frontal parts of our rock glaciers and their rooting zones relate to long periods of active development. Similar conclusions are presented by Kellerer-Pirklbauer (2008), Rode and KellererPirklbauer (2011) or Scapozza et al. (2014).

There seems agreement that surface-exposure ages of rock glacier need to be treated as minimum ages (Frauenfelder et al., 2005; Kellerer-Pirklbauer et al., 2008). Although incorporation of older boulders and accumulation of fresh rock fall debris are processes potentially disturbing any constant trend of $R$-values, the results of both longitudinal profiles make it very unlikely that any such processes execute substantial influence at Irishman Stream. This in mind, the age estimates for both rock glaciers based on the lowermost transverse ridges are close to the TCND ages of Late Glacial and early-Holocene moraines (Kaplan et al., 2010) and may, therefore, be interpreted as rather representative than only as minimum age for initiation of rock glacier development. The morphology of rock glacier 2 shows similarities with Icelandic rock glacier having experienced two phases of (re-)formation during the Holocene (KellererPirklbauer et al., 2008). Although the age difference of $c .1300$ years between its ridges 3 and 4 (samples SS 313/314; see Figure 5) is comparable to other measurements and because we are not aware of any pronounced climate variation that could be related to such a process, this assumption supported by the rock glacier morphology cannot be ruled out.

Application of the SHD age-calibration curve (Figure 6) yields early-Holocene ages between roughly 12,000 and 10,500 years ago for the lowermost rock glacier surface ridges that, as explained above, can be considered as fairly accurate estimate for the onset of their formation. There seems no reason to challenge the reliability of Kaplan et al.'s (2010) TCND ages underlying the construction of the SHD age-calibration curve. Their detailed reporting allowed exact location and all Schmidt-hammer samples were taken using calibrated instruments and identical sample designs. Of course, future improvement of the regional TCND scaling scheme that currently seems to be underway (Fink et al., 2017) may provide slightly modified numerical age estimates for the fixed points applied for the SHD calibration curve and, as a consequence, require re-calculation of the SHD age estimates.
But apart from the fact that there will always be some degree of uncertainty with TCND age estimates that cannot be completely resolved (e.g. the subjective estimation of erosion/weathering rates or required snow shielding, application of arithmetic means of moraine ridges vs individual ages for the actually sampled part of it), the ages of the lowermost rock glacier ridges will remain comparatively close to the (potentially modified) ages of the fixed points from Kaplan et al. (2010) employed here. The age of $100 \pm$ 100 years for the 'young' control point was somewhat arbitrary, set on the basis of visual impression and the overall morphological situation. These $R$-values are similar to those of lateHolocene/'LIA' moraines in glacier forelands in Aoraki/Mt Cook (Winkler and Corbett, 2014) especially if a slightly different lithology (occurrence of harder semi-schist together with typical 'greywacke') is considered. Even by increasing the age of the 'young control' by a few hundred years, the age estimates for the lower transverse ridges would only change insignificantly. Because we followed well-established procedures with the construction of such SHD calibration curves (cf. Matthews et al., 2013, 2014; Matthews and Owen, 2010; Matthews and Winkler, 2011), we review our age estimates as reliable for this type of landform.

Late Glacial moraine formation at Irishman Stream corresponds to advances during the Antarctic cold reversion (ACR) in the Southern Alps (Barrell et al., 2011) and was followed by a continuous retreat until formation of the two inner moraines belts around 12,000 and 11,500 years ago, accordingly (Kaplan et al., 2010; see also Doughty et al., 2013). Our dating of initial rock glacier formation would require almost complete disappearance of the former Irishman Stream glacier shortly (i.e. a few centuries) afterwards during early Holocene. Intact morphology of the two rock glaciers studied and neighbouring features only allows for limited glaciation by three or four small individual glaciers close to the headwall. Rock glacier morphology, their location directly at the foot of debris source (cf. Figure 2) and the remarkable linear trend of mean $R$-values for the rock glacier ridges are, furthermore, evidence against the hypothesis that the rock glacier originated in early-Holocene glaciers becoming substantially covered by debris and developed according to the ice-core structure model (cf. Janke et al., 2013). Although they are not mapped as individual features, rock glacier I and II can be traced as belonging to two stratigraphic subdivisions dated to 4000 and 3000 years old on the map of Birkeland (1982). But because also all of Kaplan et al.'s (2010) Late Glacial/early-Holocene moraines belong to the same stratigraphic subdivision, those numerical ages severely underestimate the true ages and can easily be rejected. Whereas the age difference between lowermost and uppermost rock glacier ridges of our SHD age estimates clearly exceed the difference suggested by Birkeland (1982), his subdivision at least correctly reflects the close age between the lowermost rock glacier ridges and the inner Late Glacial/early-Holocene moraines.

On Figure 2, three presumed moraine ridges can be seen in the upper area between rock glacier I and II. They have also been mapped by Kaplan et al. (2010), but not dated or investigated further. The lowermost of these three ridges is mapped as part of the 3000-year subdivision by Birkeland (1982) and seems to be marginally overridden by the rock glacier to the immediate left of rock glacier II. This together with Birkeland's stratigraphic classification and its morphological appearance suggests it belongs to the old early-Holocene moraine sequence. The two uppermost moraines that likely correlate to similar features in Irishman Stream valley head have not been investigated and could represent the local 'LIA' or late-Holocene 'LIA'-type events as their morphology appears quite 'fresh'. This assumption corresponds to their classification by Birkeland (1982) as $250 / 100$ years old. 
Unlike the valley head of Whale Stream in the central Ben Ohau range immediately to the North (Kaplan et al., 2013), there is no evidence of any further early or additional mid-Holocene glacial activity at Irishman Stream after the former Irishman Stream glacier seems to have almost disappeared and initiation of rock glacier formation started between $c$. 12,000 and 10,500 years ago. This is partly contradictory to established glacier and climate chronologies for the Southern Alps (Putnam et al., 2012; Schaefer et al., 2009) and not entirely what would be expected with the gradual regional warming trend during the Holocene (Kaplan et al., 2013; see introduction). If air temperatures are the most important drivers of glacier variability in the Southern Alps as claimed by Anderson and Mackintosh (2006) or Mackintosh et al. (2017), one would expect moraine sequences representing shortterm fluctuations during a constant decrease of glacier expansions and activity from the old early Holocene towards the 'LIA'. But the model of a regional oscillating glacier retreat from Late Glacial until c. 6500 years ago (Putnam et al., 2012) cannot be supported on the basis of our results of high SHD age estimates of the lowermost rock glacier ridges and because of the excluding nature of rock glaciers and major glacier activity. Although the dynamic geomorphological process systems in the Southern Alps could theoretically easily have eroded or buried any evidence of such glacial activity (Kaplan et al., 2013; Putnam et al., 2012), Winkler and Matthews (2010) as well as Kirkbride and Winkler (2012) stress that the lack of evidence should not be misinterpreted as actual evidence. Putnam et al.'s (2012) suggested combination of the glacier chronology for Cameron Glacier in the Arrowsmith Range exhibiting rare early-Holocene moraines with those of Hooker, Mueller and Tasman Glaciers in Aoraki/Mt Cook National Park lacking any evidence of glacier activity prior to 6500 years ago (Schaefer et al., 2009) has attracted criticism (Winkler, 2014). In general, reliable evidence about earlyHolocene glacier activity in the Southern Alps is very fragmentary at best and absent from large valley glacier east and west of the Main Divide. Different environmental/climatic conditions (more easterly location of Cameron Glacier), non-comparable glaciological properties (regarding glacier sizes and supraglacial debris cover) and obvious discrepancies with suggested lateHolocene advances reported from the glaciers create a considerable level of uncertainty for such a synthesis. Currently, it cannot be judged whether the reported evidence from Whale Stream and Cameron Glacier represents a true pattern for small, high-altitude glaciers in the eastern Southern Alps, or just individual glacier behaviour driven by local factors. Our data from Irishman Stream require at least taking the latter mentioned possibility into consideration.

Initiation and first major development of both rock glaciers required permafrost. Current distribution at their locality (Sattler et al., 2016) and climatic conditions that prevailed during the onset of the Holocene make that very likely (Doughty et al., 2013). By contrast, our SHD age constraints for rock glacier formation between 12,000 and 10,500 years ago followed by an extended period of active development would much better fit the long-term palaeoclimatic record (Kaplan et al., 2013) than any proposed mid- to late-Holocene age (Birkeland, 1982). It defines a southern hemispheric pattern naturally different to the northern hemisphere where cooling following the Holocene Thermal Optimum led to a phase of late-Holocene rock glacier formation (Janke et al., 2013; Kellerer-Pirklbauer, 2008; Scapozza et al., 2014). If confirmed at other sites across the Southern Alps, rock glacier formation during the first part of the early Holocene also bears potential implications for the regional glacier history. It would require that Late Glacial glaciers had evacuated the areas subsequently occupied by rock glaciers rather quickly and experienced more retracted positions during the early Holocene. With the gradual increase in solar insolation and air temperatures over the entire Holocene, only a drop in precipitation would create a scenario of favourable climatic conditions for rock glaciers with simultaneous unfavourable ones for glaciers. The timing of major Holocene glacier advances during the late-Holocene pre-dating the 'LIA' (Schaefer et al., 2009; Solomina et al., 2015; Winkler, 2014) coincides with increasing intensity of westerly airflow over New Zealand (Turney et al., 2017) and could give evidence that in addition to air temperatures, also atmospheric circulation patterns and precipitation need to be considered as important drivers of glacier fluctuations in the Southern Alps.

Summarising, the abovementioned difference between neighbouring Whale Stream and Irishman Stream is consistent with considerable local differences and existing uncertainties with the Holocene palaeoclimatic record for the Southern Alps (cf. Rezninchenko et al., 2016; Winkler, 2014; Winkler and Matthews, 2010). Further investigation into the age constraints of rock glaciers within the area would, therefore, utilise a yet unexplored palaeoclimatic archive and will potentially improve our knowledge about the regional Holocene glacier and climate history.

\section{Conclusion}

Our study shows that SHD using an electronic Schmidt-hammer (SilverSchmidt) can successfully be applied for the dating of rock glaciers in the Southern Alps of New Zealand and is efficient with obtaining large sets of raw data. Longitudinal transects on selected rock glaciers reveal a clear trend of decreasing $R$-values (increasing surface weathering and exposure age) from rock glacier rooting zones towards their front, only altered at the front of 'active' ridges by toppling and relocation of boulders. It supports the ideas that surface ridges at the surface of a rock glacier remain mostly stable once developed and the transfer of blocks at the rock glacier surface being a rather 'passive' process without persistent rotation or similar disturbance.

Previously published numerical ${ }^{10} \mathrm{Be}$ cosmogenic nuclide ages (Kaplan et al., 2010) enabled the calculation of SHD age-calibration curves and the lowermost transverse surface ridges of the rock glacier are dated to $c .12,000$ and 10,500 years, respectively. These age estimates indicate rock glacier initiation during or shortly after Termination 1 , thereby requiring a fast disappearance of the former (Late Glacial) Irishman Stream glacier at the onset of the Holocene. Although it cannot be judged whether the rock glaciers studied have been active during the entire Holocene or only during multiple time periods within, their intact morphology and position excludes any major glacial activity at Irishman Stream since their initial development. This assumed extended activity during the Holocene combined with the timing of their initiation has palaeoclimatic implications that need to be explored further once it is ensured it constitutes a regional pattern. It opens for the hypothesis that climatic conditions during early Holocene were favourable for rock glacier initiation but less favourable for glaciers, pointing towards comparatively dry conditions in the light of the proposed gradual increase in air temperatures during the entire Holocene. This hypothesis would also challenge the view that air temperature is the sole major climate driver of glacier variability in the Southern Alps as the vast majority of evidence for major Holocene glacier advances available dates from the mid- and late Holocene postdating an intensification of westerly airflow. Future work exploring the palaeoclimatic potential of rock glacier in the Southern Alps to establish consolidated regional patterns seems, therefore, of high priority.

\section{Acknowledgements}

The authors wish to express their sincere thanks to Thomas Büche for preparing Figure 1. Research and on-site landing permissions 
were granted by the Department of Conservation's Regional Office. Eva Kaufung and Grace O'Sullivan assisted during fieldwork in 2014, Thomas Büche and Johanna Springer in 2016.

\section{Funding}

The author(s) received no financial support for the research, authorship and/or publication of this article.

\section{References}

Anderson B and Mackintosh A (2006) Temperature change is the major driver of late-glacial and Holocene glacier fluctuations in New Zealand. Geology 34: 121-124.

Ballantyne CK, Black NM and Finley DP (1989) Enhanced boulder weathering under late-lying snowpatches. Earth Surface Processes and Landforms 14: 745-750.

Ballantyne CK, Black NM and Finley DP (1990) Use of the Schmidt test hammer to detect enhanced boulder weathering under late-lying snowpatches. Earth Surface Processes and Landforms 15: 471-474.

Barrell DJA, Andersen BG and Denton GH (2011) Glacial Geomorphology of the Central South Island (GNS Science Monographs 27). Lower Hutt: GNS Science.

Barsch D (1988) Rock glaciers. In: Clark MJ (ed.) Advances in Periglacial Geomorphology. Chichester: Wiley, pp. 69-90.

Barsch D (1996) Rock Glaciers - Indicators for the Present and Former Geoecology in High Mountain Environments. Berlin: Springer.

Birkeland PW (1982) Subdivision of Holocene glacial deposits, Ben Ohau Range, New Zealand, using relative-dating methods. Geological Society of America Bulletin 93: 433449.

Böhlert R, Compeer M, Egli M et al. (2011a) A combination of relative-numerical dating methods indicates two high Alpine rock glacier activity phases after the glacier advance of the Younger Dryas. The Open Geography Journal 4: $115-130$

Böhlert R, Egli M, Maisch M et al. (2011b) Application of a combination of dating techniques to reconstruct the Lateglacial and early Holocene landscape history of the Albula region (eastern Switzerland). Geomorphology 127: 1-13.

Brazier V, Kirkbride MP and Owens IF (1998) The relationship between climate and rock glacier distribution in the Ben Ohau Range, New Zealand. Geografiska Annaler: Series A, Physical Geography 80: 193-207.

Chater AM and Sturman AP (1998) Atmospheric conditions influencing the spillover of rainfall to lee of the Southern Alps, New Zealand. International Journal of Climatology 18: 7792.

Chinn TJH (1981) Use of rock weathering-rind thickness for Holocene absolute age-dating in New Zealand. Arctic and Alpine Research 13: 33-45.

Chinn TJH, Winkler S, Salinger MJ et al. (2005) Recent glacier advances in Norway and New Zealand: A comparison of their glaciological and meteorological causes. Geografiska Annaler: Series A, Physical Geography 87: 141-157.

Clare GR, Fitzharris BB, Chinn TJH et al. (2002) Interannual variation in end-of-summer snowlines of the Southern Alps of New Zealand, and relationships with southern hemisphere atmospheric circulation and sea surface temperature patterns. International Journal of Climatology 22: 107-120.

Clark DH, Steig EJ, Potter N et al. (1998) Genetic variability of rock glaciers. Geografiska Annaler: Series A, Physical Geography 80: 175-182.

Cossart E, Fort M, Bourles D et al. (2010) Climatic significance of glacier retreat and rockglaciers re-assessed in the light of cosmogenic dating and weathering rind thickness in Clarée valley (Briançonnais, French Alps). Catena 80: 204-219.
Cox SC and Barrell DJA (2007) Geology of the Aoraki AreaGeological Map 1:250,000 (Q-Map 15). Lower Hutt: GNS Science.

Doughty AM, Anderson BM, Mackintosh AN et al. (2013) Evaluation of Lateglacial temperatures in the Southern Alps of New Zealand based on glacier modelling at Irishman Stream, Ben Ohau Range. Quaternary Science Reviews 74: 160-169.

Fink D, Rother H, Woodward C et al. (2017) The last deglaciation in New Zealand; revisiting the Misery moraines at Arthur's Pass in the Southern Alps of New Zealand. In: 19th EGU General Assembly 2017, Vienna, 23-28 April, European Geosciences Union, Geophysical Research Abstracts 19: 11332.

Fitzharris BB, Clare GR and Renwick J (2007) Teleconnections between Andean and New Zealand glaciers. Global and Planetary Change 59: 159-174.

Frauenfelder R, Laustela R and Kääb A (2005) Relative age-dating of Alpine rock glaciers. Zeitschrift für Geomorphologie N.F 49: 145-166.

Fuchs MC, Böhlert R, Krbetschek M et al. (2013) Exploring the potential of luminescence methods for dating Alpine rock glaciers. Quaternary Geochronology 18: 17-33.

Griffiths GA and McSaveney MJ (1983) Distribution of mean annual precipitation across some steepland regions of New Zealand. New Zealand Journal of Science 26: 197-209.

Haeberli W, Brandova D, Burga C et al. (2003) Methods for absolute and relative age dating of rock-glacier surfaces in alpine permafrost. In: Phillips M, Springman S and Arenson L (eds) Proceedings of the 8th International Conference on Permafrost. Zürich: Swets \& Zeitlinger, Lisse, pp. 343-348.

Haeberli W, Hallet B, Arenson L et al. (2006) Permafrost creep and rock glacier dynamics. Permafrost and Periglacial Processes 17: 189-214.

Haeberli W, Kääb A, Wagner S et al. (1999) Pollen analysis and $14 \mathrm{C}$ age of moss remains in a permafrost core recovered from the active rock glacier Murtèl-Corvatsch, Swiss Alps: Geomorphological and glaciological implications. Journal of Glaciology 43: 1-8.

Henderson RD and Thompson SM (1999) Extreme rainfalls in the Southern Alps of New Zealand. Journal of Hydrology 38: 309-330.

Humlum O (1988) Rock glacier appearance level and rock glacier initiation line altitude: A methodological approach to the study of rock glaciers. Arctic and Alpine Research 20: $160-178$.

Humlum O (1998) The climatic significance of rock glaciers. Permafrost and Periglacial Processes 9: 375-395.

Janke JR, Regmi NR, Giardino JR et al. (2013) Rock glaciers. In: Shroder J, Giardine JR and Harbor J (eds) Treatise on Geomorphology, Volume 8: Glacial and Periglacial Geomorphology. San Diego, CA: San Diego Academic Press, pp. 238-273.

Jeanneret F (1975) Blockgletscher in den Südalpen Neuseelands. Zeitschrift für Geomorphologie N.F 19: 83-94.

Kääb A, Frauenfelder R and Roer I (2007) On the response of rock glacier creep to surface temperature increase. Global and Planetary Change 56: 172-187.

Kaplan MR, Schaefer J, Denton GH et al. (2010) Glacier retreat in New Zealand during the Younger Dryas Stadial. Nature 467: 194-197.

Kaplan MR, Schaefer JM, Denton GH et al. (2013) The anatomy of long-term warming since $15 \mathrm{ka}$ in New Zealand based on net glacier snowline rise. Geology 41: 887-890.

Kaplan MR, Schaefer JM, Strelin JA et al. (2016) Patagonian and southern South Atlantic view of Holocene climate. Quaternary Science Reviews 141: 112-125.

Kellerer-Pirklbauer A (2008) The Schmidt-Hammer as a relative age dating tool for rock glacier surfaces: Examples 
from northern and central Europe. In: Proceedings of the Ninth International Conference on Permafrost, Fairbanks, 29 June-3 July, Institute of Northern Engineering, pp. 913918.

Kellerer-Pirklbauer A, Wangensteen B, Farbrot H et al. (2008) Relative surface age-dating of rock glacier systems near Hólar in Hjaltadalur, Northern Iceland. Journal of Quaternary Science 23: 137-151.

Kirkbride MP and Brazier V (1995) On the sensitivity of Holocene talus-derived rock glaciers to climate change in the Ben Ohau Range, New Zealand. Journal of Quaternary Science 10: 353-365.

Kirkbride MP and Winkler S (2012) Timescales of climate variability, glacier response, and chronological resolution: Issues for correlation of Late Quaternary moraines. Quaternary Science Reviews 46: 1-29.

McGregor VR (1967) Holocene moraines and rock glaciers in the central Ben Ohau Range, Southern Canterbury, New Zealand. Journal of Glaciology 6: 737-748.

Mackintosh AN, Anderson BM, Lorrey AM et al. (2017) Regional cooling caused recent New Zealand glacier advances in a period of global warming. Nature Communications 8: 14202.

Matthews JA and Owen G (2010) Schmidt hammer exposure-age dating: Developing linear age-calibration curves using Holocene bedrock surfaces from the JotunheimenJostedalsbreen regions of southern Norway. Boreas 39: $105-115$.

Matthews JA and Winkler S (2011) Schmidt-hammer exposureage dating (SHD): Application to early Holocene moraines and a reappraisal of the reliability of terrestrial cosmogenicnuclide dating (TCND) at Austanbotnbreen, Jotunheimen, Norway. Boreas 40: 256-270.

Matthews JA, Nesje A and Linge H (2013) Relict talus-foot rock glaciers at Øyberget, Upper Ottadalen, southern Norway: Schmidt hammer exposure ages and palaeoenvironmental implications. Permafrost and Periglacial Processes 24: 336346.

Matthews JA, Wilson P and Mourne RW (2017) Landform transitions from pronival ramparts to moraines and rock glaciers: A case study from the Smørbotn cirque, Romsdalsalpane, southern Norway. Geografiska Annaler: Series A, Physical Geography 99: 15-37.

Matthews JA, Winkler S and Wilson P (2014) Age and origin of ice-cored moraines in Jotunheimen and Breheimen, southern Norway: Insights from Schmidt-hammer exposure-age dating. Geografiska Annaler: Series A, Physical Geography 96: 531548.

Menounos B, Clague JJ, Osborn G et al. (2013) Latest Pleistocene and Holocene glacier fluctuations in southernmost Tierra del Fuego, Argentina. Quaternary Science Reviews 77: 70-79.

Proceq SA (2012) Operating Instructions Silverschmidt \& Hammerlink. Schwerzenbach: Proceq SA.

Proceq SA (2014) Operating Instructions Rockschmidt \& Rocklink. Schwerzenbach: Proceq SA.

Putnam AE, Schaefer JM, Barrell DJA, et al. (2010) In situ cosmogenic $10 \mathrm{Be}$ production-rate calibration from the Southern Alps, New Zealand. Quaternary Geochronology 5: 392-409.

Putnam AE, Schaefer JM, Denton GH et al. (2012) Regional climate control of glaciers in New Zealand and Europe during the pre-industrial Holocene. Nature Geoscience 5: $627-630$

Rezninchenko NV, Davies TRH and Winkler S (2016) Revised palaeoclimatic significance of Mueller Glacier moraines, Southern Alps, New Zealand. Earth Surface Processes and Landforms 41: 196-207.
Rode M and Kellerer-Pirklbauer A (2011) Schmidt-hammer exposure-age dating (SHD) of rock glaciers in the Schöderkogel-Eisenhut area, Schladminger Tauern Range, Austria. The Holocene 22: 761-771.

Sattler K (2016) Periglacial preconditioning of debris flows in the Southern Alps, New Zealand. Dordrecht: Springer.

Sattler K, Anderson B, Mackintosh A et al. (2016) Estimating permafrost distribution in the maritime Southern Alps, New Zealand, based on climatic conditions at rock glacier sites. Frontiers in Earth Sciences 4: Article 4.

Scapozza C (2015) Evolution des glaciers et du pergélisol depuis le dernier maximum glaciaire dans la région du mont Gelé-Mont Fort (Alpes Valaisannes, Suisse): chronologie, modalités de la dernière déglaciation et datations des âges d'exposition à l'aide du marteau de Schmidt. Quaternaire: Revue De L'association Française Pour L'étude Du Quaternaire 26: 141-173.

Scapozza C, Lambiel C, Bozzini C et al. (2014) Assessing the rock Glacier kinematics on three different timescales: A case study from the southern Swiss Alps. Earth Surface Processes and Landforms 39: 2056-2069.

Schaefer JM, Denton GH, Kaplan M et al. (2009) High-frequency Holocene glacier fluctuations in New Zealand differ from the northern signature. Science 324: 622-625.

Shakesby RA, Matthews JA and Owen G (2006) The Schmidt hammer as a relative-age dating tool and its potential for calibrated-age dating in Holocene glaciated environments. Quaternary Science Reviews 25: 2846-2867.

Shakesby RA, Matthews JA, Karlén W et al. (2011) The Schmidt hammer as a Holocene calibrated-age dating technique: Testing the form of the R-value-age relationship and defining the predicted-age errors. The Holocene 21: 615-628.

Solomina ON, Bradley RS, Hodgson DA et al. (2015) Holocene glacier fluctuations. Quaternary Science Reviews 111: 9-34.

Stahl T, Winkler S, Quigley M et al. (2013) Schmidt hammer exposure-age dating (SHD) of late Quaternary fluvial terraces in New Zealand. Earth Surface Processes and Landforms 38: $1838-1850$.

Strelin JA, Kaplan MR, Vandergoes MJ et al. (2014) Holocene glacier history of the Lago Argentino basin, Southern Patagonian Icefield. Quaternary Science Reviews 101: 124-145.

Tait A, Henderson R, Turner R et al. (2006) Thin plate smoothing spline interpolation of daily rainfall for New Zealand using a climatological rainfall surface. International Journal of Climatology 26: 2097-2115.

Turney CSM, Wilmshurst JM, Jones RT et al. (2017) Reconstructing atmospheric circulation over southern New Zealand: Establishment of modern westerly airflow 5500 years ago and implications for Southern Hemisphere Holocene climate change. Quaternary Science Reviews 159: 77-87.

Wanner H, Solomina O, Grosjean M et al. (2011) Structure and origin of Holocene cold events. Quaternary Science Reviews 30: 3109-3123.

Whalley WB and Martin HE (1992) Rock glaciers: II models and mechanisms. Progress in Physical Geography 16: 127-186.

Winkler S (2005) The Schmidt hammer as a relative-age dating technique: Potential and limitations of its application on Holocene moraines in Mt Cook National Park, Southern Alps, New Zealand. New Zealand Journal of Geology and Geophysics 48: 105-116.

Winkler S (2009) First attempt to combine terrestrial cosmogenic nuclide $(10 \mathrm{Be})$ and Schmidt hammer relative-age dating: Strauchon Glacier, Southern Alps, New Zealand. Central European Journal of Geosciences 1: 274-290. 
Winkler S (2014) Investigation of late-Holocene moraines in the western Southern Alps, New Zealand, applying Schmidt-hammer exposure-age dating. The Holocene 24: 48-66.

Winkler S and Corbett D (2014) Potential improvement of Schmidt-hammer exposure-age dating (SHD) of moraines in the Southern Alps, New Zealand, by application of the new electronic Schmidt-hammer. In: 16th EGU General Assembly 2014, Vienna, 27 April-2 May, European Geosciences Union, Geophysical Research Abstracts 16: 1268
Winkler S and Matthews JA (2010) Holocene glacier chronologies: Are 'high-resolution' global and inter-hemispheric comparisons possible? The Holocene 20: 1137-1147.

Winkler S and Matthews JA (2014) Comparison of electronic and mechanical Schmidt hammers in the context of exposure-age dating: Are Q- and R-values interconvertible? Earth Surface Processes and Landforms 39: 1128-1136.

Winkler S, Matthews JA, Mourne RW et al. (2016) Schmidt-hammer exposure ages from periglacial patterned ground (sorted circles) in Jotunheimen, Norway, and their interpretative problems. Geografiska Annaler: Series A, Physical Geography 98: 265-285. 